\title{
Experimental Investigation and Analysis of Rice Bran Additive Fuel in A Spark Ignition Engine
}

\author{
Nithin Raj ${ }^{1}$, Praveen Maruthur ${ }^{2}$, Rahul Mohan ${ }^{3}$,Shaik Usman Shah ${ }^{4}$ \\ 1Department of Automobile engineering, Nehru College of Engineering and Research Centre, Kerala, India \\ 2Department of Mechanical Engineering, Nehru college of Engineering and Research Centre, Kerala, India \\ 3Department of Automobile engineering, Nehru College of Engineering and Research Centre, Kerala, India \\ 4Department of Automobile Engineering, Nehru college of Engineering and Research Centre, Kerala, India \\ 1nithinraj003@gmail.com \\ 2pmaruthur66@gmail.com \\ 3rahulmohan.tvmala@gmail.com \\ 4shaikusmanshah@gmail.com
}

\begin{abstract}
Spark ignition engine is preferred locomotive prime mover due to its smooth operation and low maintenance. The petrol is fossil fuel which is limited in reservoirs causes varieties of study in search of alternative fuel for SI engine, where alcohol promises best alternative fuel. In this paper, performance and emission analysis of a SI engine using the ROEE-Petrol Blend and Petrol were carried out. In this novel, it has been found that the addition of fuel has increased the performance characteristics (Mechanical efficiency), decreased SFC along with considerable reduction in emissions from the optically accessible engine as the test rig with optimum power production. Experiments were carried with variable speed constant load and constant speed variable load methods.
\end{abstract}

Keyword- Internal combustion engine, ROEE- Rice Bran Oil Ethyl Ester, SI Engine, SFC-Specific fuel consumption, emissions.

\section{INTRODUCTION}

Unsustainable demands of petroleum fuels, increased global warming threats and environmental degradation matters have necessitated for development and adaptation to ecofriendly and renewable type of energy resources all over the world. This experimental fuel is an alternative fuel like biodiesel and ethanol which are being projected as substitutes to petrol. Their adoptability to existing engine designs, reduced toxic emissions, comparable engine performances and choice for wide variety of feed stocks have made them attractive and have encouraged many countries to initiate several biofuel developmental programs in their respective zones. To reduce the dependency of imported petroleum fuels, most of the biofuels produced at present are blended with Diesel/gasoline and are used as economic and energy drives. Research and development of bio fuels can bring various benefits including immortality, reduction in greenhouse gas emission, regional development, stability in supplying raw materials, social and agriculture structure stability and development and thereby consistent growth of the economy. The notable advantage of these fuels compared to conventional fuels is their high cetane number, reduced sulphur content and pollution reduction due to it there by they have upper hand due to their renewability and environment friendly character. Based on research consuming biodiesel can help considerably in reducing the consumption of fossil fuels and the adverse conditions they create due to their toxic emissions. Therefore, the purpose of this research work is to investigate performance and emission characteristics of an SI engine which utilizes various proportions of petrol and bio fuel blends. The experimental fuel is a mixture of fossil fuel and liquid bio fuel. The emission from automobile has been major cause of pollution in and major constituent in creating air toxicity in urban areas. Till date many methods were developed and indeed used to reduce toxic engine exhaust emissions. Studies have shown that engine exhausts are considerably reduced by using blends of alcohol and biodiesels. In a study, the effect of compression ratio on performance of an SI engine using $78 \%$ gasoline and $22 \%$ ethanol blend (E22) and aqueous ethanol (E100) was investigated. The results showed that engine performance was improved in high compression ratios with both fuels compared to gasoline. The result showed there was an increase in brake specific fuel consumption. Also in an investigation, hydrous ethanol (6.8\% water) was used as fuel for high speed engine and the results were that torque, brake mean effective pressure (BMEP), brake power, thermal efficiency and specific fuel consumption (SFC) were higher. Also, CO, HC decreased and CO2, NOx increased using hydrous ethanol. As previous studies show, only mixtures of two or three fuels were used to study performance and emissions characteristics of SI engine. Here the experimental fuel is a blend of two type's fuels and two types of biofuels. After preparing mixtures some critical significant properties of blends were investigated, measured and compared with petrol. 


\section{A.Fuel Preparation}

\section{MATERIALS AND METHODS}

As mentioned earlier experimental fuel is mixture of two types of fuels and two types of bio fuels, a mixture of Petrol, ethanol, biodiesel and diesel. Chemical Proportion used in fuel is (10 vol\% Ethanol, $2.5 \mathrm{vol} \%$ Biodiesel, 2.5 vol\% Diesel and 85 vol\% Petrol).

The various fuel properties of Petrol, diesel, ethanol and biodiesel produced from rice bran oil and their blends were determined based on the ASTM standards.

TABLE I. Properties of Selected Fuels

\begin{tabular}{|l|c|c|c|c|}
\hline Description & Petrol & Ethanol & Biodiesel & Diesel \\
\hline Density, $\mathrm{kg} / \mathrm{L}$ & 0.70 & 0.789 & 0.86 & 0.832 \\
\hline Flash Point, ${ }^{0} \mathrm{C}$ & -43 & 63 & 120 & $52-90$ \\
\hline Specific Gravity & 0.713 & 0.787 & 0.88 & 0.85 \\
\hline Boiling Point, ${ }^{0} \mathrm{C}$ & 95 & 78.37 & $180-360$ & 350 \\
\hline Calorific Value, $\mathrm{MJ} / \mathrm{kg}$ & 44.4 & 29.70 & 36.70 & 45.40 \\
\hline
\end{tabular}

\section{B.Experimental Apparatus}

The experimental set up consists of a spark ignition engine, engine test bed with a self-excited DC generator coupled to a resistance load bank.

TABLE III. Test engine specifications

\begin{tabular}{|l|l|}
\hline Engine & Greaves \\
\hline BP & $2.2 \mathrm{KW}$ \\
\hline RPM & $3000 \mathrm{RPM}$ \\
\hline No of Cylinders & Single \\
\hline Bore & $70 \mathrm{~mm}$ \\
\hline Stroke Length & $66.7 \mathrm{~mm}$ \\
\hline Starting & Rope and Self \\
\hline Working Cycle & Four Stroke \\
\hline Method of Ignition & Spark ignition \\
\hline Orifice Diameter & $20 \mathrm{~mm}$ \\
\hline Compression Ratio & $4.67: 1$ \\
\hline
\end{tabular}

TABLE III. DC Generator Specification

\begin{tabular}{|l|l|}
\hline Type & Self-Excited \\
\hline Power & $2.2 \mathrm{KW}$ \\
\hline Speed & $3000 \mathrm{rpm}$ \\
\hline
\end{tabular}

\section{III.FORMULAS USED}

Brake Power,

Mass of Fuel Consumed,

Specific Volume Consumption,

Actual volume of air sucked into the cylinder,

Swept Volume,

Volumetric Efficiency'

Brake Thermal or Overall Efficiency,

Mechanical Efficiency,

$$
\begin{array}{ll}
\mathrm{BP} & =\frac{\mathrm{V} * \mathrm{I}}{1000 * \eta \mathrm{gen}}, \mathrm{KW} \\
\mathrm{Mfc} & =\frac{\mathrm{X} * 0.72 * 3600}{1000 * \mathrm{t}}, \mathrm{kg} / \mathrm{hr} . \\
\mathrm{Sfc} & =\frac{\mathrm{MfC}}{\mathrm{BP}}, \mathrm{kg} / \mathrm{kW} \mathrm{hr} . \\
\mathrm{V}_{\mathrm{a}} & =\mathrm{C}_{\mathrm{d}} * \mathrm{~A} \sqrt{ } 2 \mathrm{gH}^{*} 3600, \mathrm{~m}^{3} / \mathrm{hr} . \\
\mathrm{V}_{\mathrm{S}} & =\frac{\pi}{4} \mathrm{D}^{2} \mathrm{~L} \frac{60 \mathrm{~N}}{2}, \mathrm{~m}^{3} / \mathrm{hr} . \\
\eta_{\mathrm{v}} & =\frac{\mathrm{Va}}{\mathrm{VS}} \times 100 \% \\
\eta_{\text {bth }} & =\frac{\mathrm{BP} * 3600 * 100}{\mathrm{Mfc} * \mathrm{CV}}, \% \\
\eta_{\text {mech }} & =\frac{\mathrm{BP}}{\mathrm{IP}} * 100, \% \\
\text { IP } & =\frac{\mathrm{BP}}{\eta_{\mathrm{mech}}} * 100, \%
\end{array}
$$


Indicated Thermal or Overall Efficiency, $\quad \prod_{\text {ith }} \quad=\frac{\mathrm{IP} * 3600 * 100}{\mathrm{Mfc} * \mathrm{CV}}, \%$

\section{IV.RESULTS AND DISCUSSION}

Initially several fuel blends were prepared and tested in which the performance studies of fuel with 10 vol\% Ethanol, 2.5 vol\% Biodiesel, 2.5 vol\% Diesel and 85 vol\% Petrol were used. Performance studies were made with connecting engine to $230 \mathrm{v}, 50 \mathrm{~Hz}$ AC single phase ACSupply and measurements were taken for constant speed of $3000 \mathrm{rpm}$.

From the Performance test it is found that the BP,IP,BMEP,IMEP,BTE,ITE,ME and VE of the experimental blend was more than the corresponding values of Petrol.the values of MFC and SFC was found to be lesser than the petrol. Heat balance tests shows that the unaccounted heat loss was reduced to a considerable amount which resulted in increased heat efficiency for the experimental blend fuel than petrol.

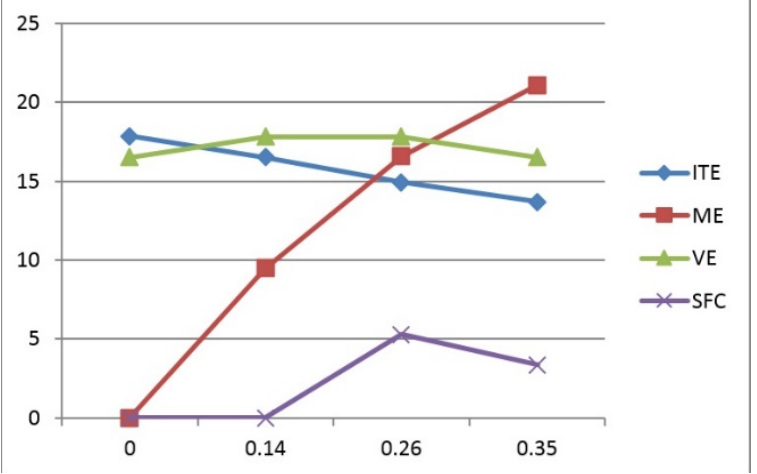

Fig.1. Performance characteristics of petrol

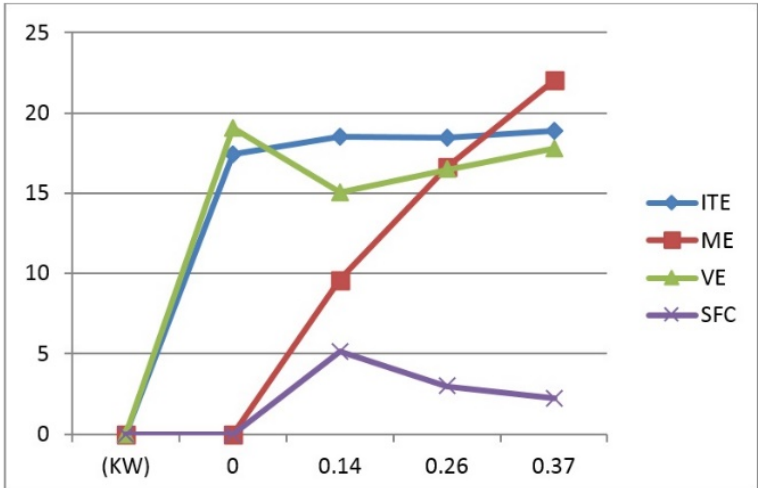

Fig.2.Performance characteristics of Experimental fuel

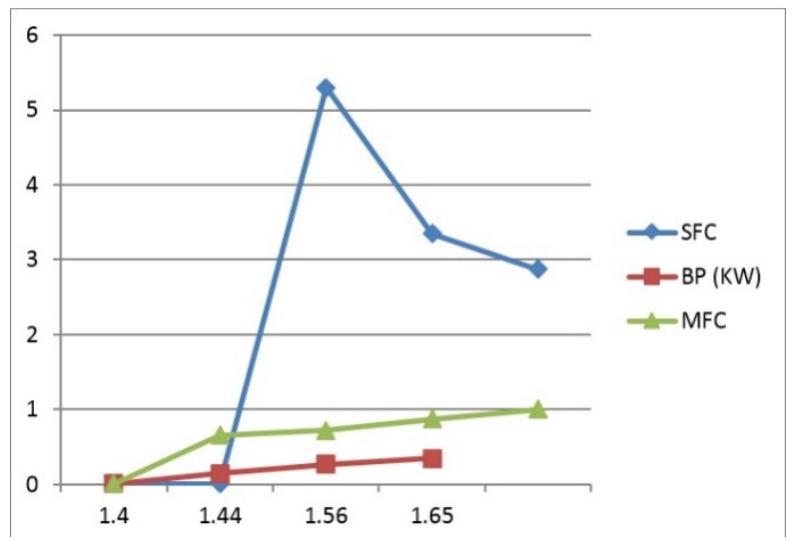

Fig.3. Performance characteristics of petrol (SFC, BP, MFC vs IP) 


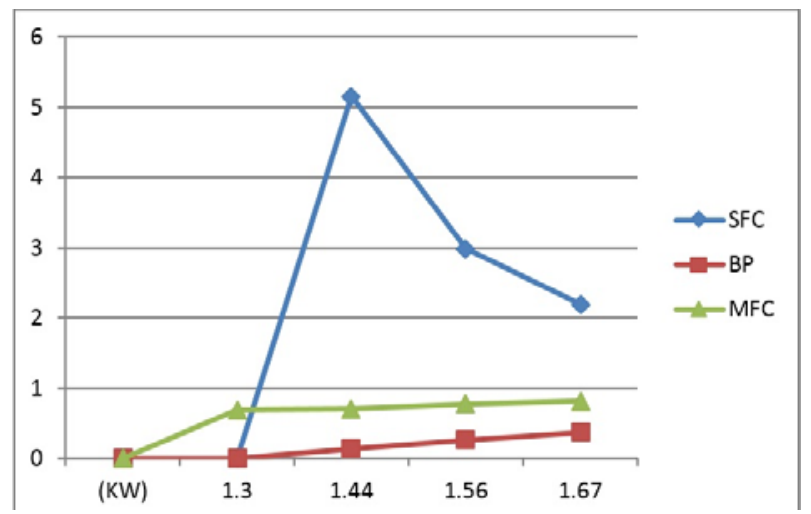

Fig.4. Performance characteristics of Experimental fuel blend (SFC, BP, MFC vs IP)

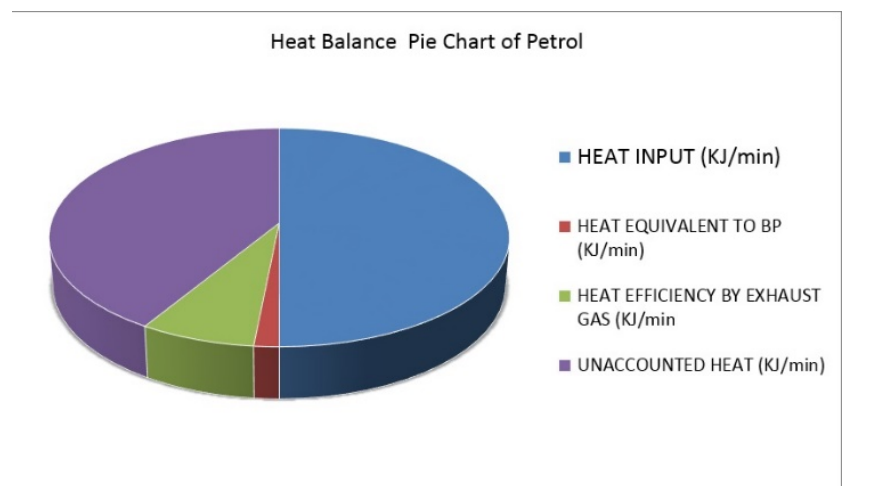

Fig.5. Heat balance sheet of Petrol

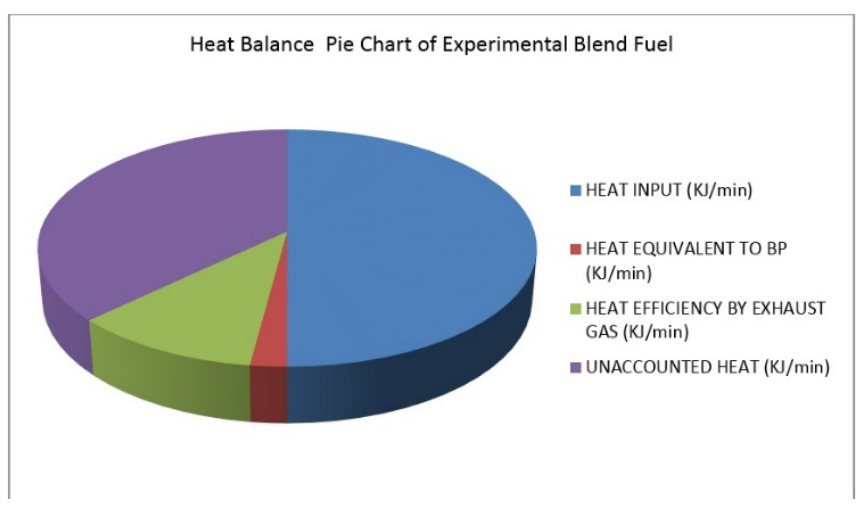

Fig.6. Heat balance sheet of experimental fuel.

\section{Conclusion}

This experimental project deals with production of biodiesel from Rice Bran oiland blending the Rice Bran oil biodiesel with ethanol, diesel and petrol. The blended fuel is tested on a Spark Ignition engine and its performance characteristics were plottedagainst petrol and compared. The mechanical efficiency of the experimental fuel is $1 \%$ more thanpetrol. Frictional power is lesser, unaccounted heat loss is found to be less than petrol.Emissionwas considerably reduced the experimental readings of the newly developed fuel shows that this can a good replacement for conventional fuels with reduced heat losses and specific fuel consumption.

\section{ACKNOWLEDGMENT}

Our endeavor stands incomplete without dedicating our gratitude to everyone who has contributed a lot towards the successful completion of our project work. We express our sincere thanks to the Nehru Group of Institutions, Kerala for providing the facility for Blending and Trans-Esterification Process in Nehru College of Pharmacy and Thermal Labs and Mechanical Labs in Nehru College of Engineering and Research Centre, Pampady and Jawaharlal College of Engineering and Technology,Lakkidi. 


\section{REFERENCES}

[1] PegahNematizade,BaratGhobadian, FathollahOmmi, holamhasan Najafi "Performance and Exhaust Emissions of a Spark Ignition Engine Using G-Series and E20 fuels". International Journal of Automotive Engineering and Technologies Vol. 2, Issue 2, pp. 55 - 63, 2013.

[2] Mukesh Kumar, OnkarSingh "Study of Biodiesel as a Fuel for CI Engines and its Environmental Effects: a Research Review" International Journal of Advances in Engineering \& Technology, Jan. 2013Vol. 5, Issue 2pp. 100-107.

[3] JitendraKumar ,DhananjayTrivedi, PrakashMahara, Ravi Butola"Performance Study of Ethanol Blended Gasoline Fuel in Spark Ignition Engine" IOSR Journal of Mechanicaland Civil Engineering (IOSR-JMCE) Volume 7, Issue 3 (Jul. - Aug. 2013), PP 71-78.

[4] Viral K Pandya, Shailesh N Chaudhary, Bakul T Patel, Parth D Patel "Experimental Study on the Effect of Methanol Gasoline, Ethanol-Gasoline and n-Butanol Gasoline Blends on the performance of 2-stroke petrol engine" International Journal of Advances in Engineering \& Technology, Nov 2011Vol. 1, Issue 5, pp. 454-461.

[5] AmbarishDatta ,Achin Kumar Chowdhuri, Bijan Kumar Mandal "Experimental Study on the Performances of Spark Ignition Engine with Alcohol-Gasoline Blends as Fuel" International Journal of Energy Engineering IJEE Vol. 2 No. 1, 2012 PP. $22-27$.

[6] SulakshanaS,Deshpande,S.V.Channapattana, Dr. A. A. Pawar " Experimental Evaluation of Diesel Engine Performance and Emissions Using Diesel/Biodiesel/Ethanol Blend Fuel”'International Journal of Emerging Technology and Advanced Engineering Volume 5, Issue 1, January 2015

[7] Dr. HiregoudarYerrennagoudaru, Manjunatha K, Chandragowda M, BasavaPrakash B "Performance \& Emission of C I Engine Using Diesel \& Ethanol Blended with Jatropa Oil” International Journal of Recent Development in Engineering and Technology Volume 2, Issue 6, June 2014

[8] Mohankumar.P,Karthikeyan.V,Visagavel.K"Study on emission control by blending ethanol with petrol in multi cylinder serviced engine", International Journal of Research in Engineering and TechnologyVolume: 03 Special Issue: 11 | NCAMESHE - 2014 | Jun2014

[9] T. Krishnaswamy and N. ShenbagaVinayagaMoorthi "Performance evaluation of diesel engine with oxygenated bio-fuel blends"ARPN Journal of Engineering and Applied Sciences vol. 7, no. 1, January 2012

[10] M. Al-Hassan, H. Mujafet and M. Al-Shannag, "An Experimental Study on the Solubility of a Diesel-Ethanol Blend and on the Performance of a Diesel Engine Fueled with DieselBiodiesel - Ethanol Blends" Jordan Journal of Mechanical and Industrial Engineering, Volume 6, Number 2, April 2012

[11] Yi- Hsu Ju and Shaik RamjanVali, "Rice Bran oil as a potential resource for biodiesel: A Review" Journal of scientific and industrial research, vol 64, November 2005 pp866-882

[12] V. Arul MozhiSelvan, R. B. Anand and M. Udayakumar, "Effects of cerium oxide nanoparticle addition in diesel and diesel-biodieselethanol blends on the performance and emission characteristics of a CI engine", ARPN Journal of Engineering and Applied Sciences, vol. 4, no. 7, September 2009

[13] Gauravtiwari, Dr. Nitinshrivastava, "Experimental investigation of ethanol blends with gasoline on SI engine”, International Journal of Engineering Research and Application ISSN: 2248-9622, Vol. 4, Issue 10(Part - 5), October 2014, pp.108-114

[14] V.Gnanamoorthi and G. Devaradjane, "Effect of Diesel-Ethanol Blends on Performance, Combustion and Exhaust Emission of a Diesel Engine", International Journal of Current Engineering and Technology, Vol.3, No.1 (March 2013)

\section{AUTHOR PROFILE}

Nithin Raj- Got B.Tech Automobile Engineering from NCERC on 2016

Praveen Maruthur- Got B.Tech Mechanical Engineering on 2011, M.Tech in Energy Engineering fromCUSAT on 2014, MBA Technology Management from Barathiyar University.

Rahul Mohan- Got B.Tech Automobile Engineering from NCERC on 2016

Shaik Usman Shah- Got DAE Diploma in Automobile Engineering from Karpagam Polytechnic College,B.E Automobile Engineering Tamilnadu college of Engineering,M.E Engineering Design from Bannari Amman Institute of Technology. 